\title{
How to wield regional power from afar: a conceptual discussion illustrated by the case of France in Central Africa
}

\author{
Frank Mattheis ${ }^{1,2,3}$ (D)
}

(c) The Author(s) 2021

\begin{abstract}
What does it take to belong to a region and exert power over it? The scholarship on regional powers has elaborated sophisticated indicators to establish nuances of power, but the depiction of the region has remained vague. Most approaches are characterised by a narrow territorial interpretation that does not properly take into account power wielded by geographically distant actors. Using the case of France in Central Africa this article argues that a distant state can a) hold a dominant share of military, economic and soft power, b) use this power for hegemonic behaviour and c) be recognised as a leader in the region by both internal and external actors. The main specificity of distant actors as regional powers is the greater necessity for a legitimising narrative. France tackles this hurdle with the help of regional organisations that reproduce imperial structures. By holding the informal status of a quasimember in regional governance structures, France participates in region-building processes from the inside rather than the outside.
\end{abstract}

Keywords Regional power $\cdot$ Central Africa $\cdot$ France $\cdot$ Regionalism $\cdot$ Regional organisations $\cdot$ Hegemony

\section{Introduction: what does "regional" in regional power entail?}

In early 2019, a convoy of 50 pick-ups from the Chadian rebel group UFR crossed the border from Libya to Chad. $900 \mathrm{kms}$ farther in the capital N'djamena, the then President of Chad Idriss Déby feared that this move could lead to an insurgency endangering his 30-year authoritarian rule. Given ineffective attempts by the

Frank Mattheis

ftmattheis@gmail.com

1 United Nations University - Institute on Comparative Regional Integration Studies (UNUCRIS), Bruges, Belgium

2 University of Pretoria, Pretoria, South Africa

3 Albert-Ludwigs-Universität Freiburg, Freiburg, Germany 
Chadian air force to curtail the rebels, Déby required external assistance. His first port of call for assistance was neither Nigeria - the military power within the neighbourhood-nor one of the African regional organisations. Upon his request, the French government deployed seven jet fighters that annihilated the convoy during four days of strikes (Vignal 2019).

From the perspective of international relations, this anecdote evokes questions of hegemony, power and region-building. Over the past decade, the scholarship on regional powers has been particularly active in analysing the interplay between such dynamics. However, such an episode would typically be discarded as a case of a region without a regional power. The present article challenges this perspective and unpacks the division between outsiders and insiders in the distribution of regional power shares. It asks whether and how a state can act as a regional power outside of its vicinity.

The scholarship on regional powers has elaborated sophisticated indicators to establish differences in power status. However, considerably less attention has been devoted to conceptualising the region of a regional power. Scholars such as Østerud (1992) or Destradi (2010) refer to geographic location as an essential part of the definition of regional power. A region is frequently labelled the "neighbourhood" of a regional power, which leaves ample room for interpretation. In some instances, scholars use "local" as synonymous for 'regional' in order to stress physical proximity (cf. Lemke 2002).

When delineating regions, the scholarship on regional powers is caught in a constraining bias of embracing pregiven geographic containers and following a narrow territorial interpretation that is a priori not warranted by its own conceptual definitions. The resulting topographic determinism restricts the region to adjacent states. It addresses power distribution within that territory and does not directly take into account region-building by or with external actors, even if they are deeply implanted in the region. The concept of "overlay" in regional security complex theory makes reference to the overwhelming presence of an external power but only in a negative manner as a constellation where a region cannot take shape (Buzan and Wæver 2003: p. 61). Subsequent scholarship has continued to debate whether or not to include external actors in the creation of a region (Hanau Santini 2017). While regions have often been treated as containers to establish the power distribution, there is also acknowledgement of the overlap and entanglement of different regional orders (Lake and Morgan 2010).

The unresolved territorial narrowness is at odds with the established theoretical body of literature on Comparative Regionalism, which acknowledges that regions are constructed social spaces with porous and instable delineations (Söderbaum 2015). Regionalisms - including projects fostered by regional powers-create and reinforce the interdependence and common identity within these dynamic spaces (Hettne 2005). Hence, the resulting regions are neither fixed nor natural (Katzenstein 2005; Fawn 2009; Shaw, Grant and Cornelissen 2011). They serve to include certain actors and territories and exclude others, which results in different regional formats overlapping and competing.

Despite those conceptual premises, the practice of Comparative Regionalism and research on regional powers overly relies on the membership of regional 
organisations to define what a region is (Mattheis 2017). This equation is often warranted. Regional organisations serve as a place for regional order to be negotiated and devised (Börzel et al. 2016). The existence and capacity of regional powers are assumed to positively correlate with those of regional organisations (Lemke 2010; Nolte 2010). Several strands of the literature have highlighted the way regional powers act through regional organisations. The creation of the Union of South American States (Unasur) has been interpreted as a way for Brazil to challenge existing regional organisations and to delineate the South American region as a sphere of influence that excludes rivals such as Mexico and the USA (Soares de Lima and Hirst 2006). South Africa has been analysed with respect to its imperial behaviour towards and within the regional organisations of which it is a member of (Taylor 2011). The relations between overlapping regional organisations oscillate between cooperation, competition and ignorance (Malamud 2013). Overlaps can indicate the existence of several projects by the same regional power (Parlar Dal, 2016) or an antagonism between a regional power on one side and a contender or counterhegemonic alliance on the other side (Riggirozzi and Tussie 2012). However, defining a region on the basis of formal membership in regional organisations poses important pitfalls.

\section{Conceptual inroads to account for external actors as regional powers}

Power constellations vary greatly depending on the shape of the region, and regional powers can be expected to promote a delineation that legitimises the exclusion of what they perceive to be rivals. It is thus crucial to expand the scope of analysis, as the membership of a regional organisation is not per se congruent with the spatial dimension of regional power. The power share is not only distributed among neighbouring states but among all actors that through their presence, practice and perception are the region. Indeed, the "neighbourhood" can stretch far beyond immediately adjacent territories, as the terms backyard for the USA in Latin America and even the Middle East (Droz-Vincent 2007) or France's pré carré in Africa indicate. Taking into account external actors with a substantial capacity in the region entails that relative indicators (e.g. the military capacity relative to all other actors in the region) need to be assessed among a larger pool of actors, thus decreasing the relative power of internal actors.

On a theoretical level, the existing conceptualisation of regional power is able to grasp a broad range of actors that fulfil the main required functions. The influential definition of regional power by Nolte (2010: p. 893) refers to "the pretension of a leading position in a [delimited] region", to being "interconnected with the region" and to "influence by means of regional governance structures". While these characteristics have been primarily associated with countries that are topographically part of the region, they enable us to capture actors that tend to be disregarded due to being external. In the same vein, Destradi (2010: p. 905) posits that two fundamental features of regional powers are to "belong to the region" and to "possess the largest power share in the region". If regions are highly porous social constructions (Katzenstein 2005), they are likely to be permeated by influential external actors that 
cannot be detached from the region and thus invariably "belong to the region". Even more detailed concepts allow for geographic broadening, such as Reich and Lebow's (2014) focus on custodianship rather than geographic implantation or Frazier and Stewart-Ingersoll's (2010) hegemony that is not restricted to physical vicinity. Excluding external actors from the analysis of regional powers is thus not only shortsighted but also leaves a vast amount of conceptual advancements underutilised.

Paying more attention to external actors also brings to the fore regions that have hitherto stayed under the radar. The concept of regional powers has been primarily derived from cases with visible internal contenders to regional leadership, thus eclipsing regions where these are apparently absent. This is partly due to the entanglement with studies of "rising powers" (Brosig 2021), which entailed a focus on states figuring in popular acronyms such as BRICS (Brazil, Russia, India, China and South Africa) and MINT (Mexico, Indonesia, Nigeria and Turkey), plus a few selected countries such as Ethiopia (Le Gouriellec 2018). However, regional power debates have underestimated the necessity to test the concept in less visible cases with different constellations of regional order. The absence of an internal regional power can indeed be a result of a substantial share of power being held by an external actor, who has in turn acquired characteristics of a regional power. Even states with a substantial power share vis-à-vis their neighbours would only be able to attain regional power if they are not superseded by an external actor, as the introductory anecdote of Nigeria and France illustrates. The presence of external actors can thus be a valid reason to explain why certain states are not able to act as regional powers, even though they possess a substantial power share vis-à-vis their direct neighbours.

The approach proposed in this paper also addresses the uneven empirical focus on the Global South in the scholarship. Although the most popular cases in the literature have waxed and waned along political oscillations-with Brazil's status declining and Turkey's ambition increasing - regional power has predominantly been a concept applied to non-Western regions. Research about for instance regional power strategies in the Baltic region (cf. Knudsen, 2017) has been less prominent andmore importantly - this knowledge has rarely been picked up by scholars working on Brazil, South Africa and other non-Western cases. This imbalance recalls the divide between Comparative Regionalism and European Studies in the 2000s, where two strands of the literature worked on regional integration, but one derived its concepts from the Global South and the other from the European Union (De Lombaerde et al. 2010). Despite the empirical bias towards cases in the Global South, there is no compelling reason not to apply the concept to Western states-in their immediate region as well as in territorially distant regions. Though not explicitly included in this paper, the line of argument presented here also paves the way for addressing non-state actors in a similar fashion as external actors by thoroughly examining their belonging to the region. Finally, the inclusion of Western states resonates with the recurrent use of the concept of imperialism in the regional power literature (Destradi 2010; Wigell 2016) and with the importance of the historic dimension of power (Fawcett 2004), in particular European colonialism, as overseas imperialism is a more limited phenomenon in the Global South.

Based on the preceding critique, this article seeks to address a mismatch in regional power scholarship between theory and concepts on the one hand and 
empirical application on the other hand. While theory does not prescribe strict territorial limits and applies to potentially all states, empirical studies have focused on cases located in the Global South within territorially limited region. The aim of the paper is to establish whether and how a distant state acts as a regional power. To this effect, two research questions will be addressed: is France a regional power in Central Africa and if so, how does it overcome constraints associated with the lack of territorial proximity?

\section{Case study: France in Central Africa from a regional power perspective}

The designation and delineation of a region are always contestable, and Central Africa is no exception. Different geographical, historical, cultural and political notions yield different results as to what should be included and excluded in a region coined Central Africa. In line with the research interest of this paper, Central Africa has been chosen as a most likely case to examine whether an external state can be considered a regional power in a region hitherto disregarded by the literature as a power void. ${ }^{1}$ To serve as an illustrative case of France as a regional power, the notion of Central Africa applied in this paper follows a political delineation of a group of countries that are institutionally bound to France. Central Africa is equated with the Central African Economic and Monetary Community (CEMAC), constituted by the member states Cameroon, the Central African Republic (CAR), Chad, the Republic of Congo, Equatorial Guinea and Gabon. ${ }^{2}$ CEMAC is a long-standing formal regional organisation dating back to 1964 and also corresponds to the Central African CFA zone which shares a common currency. It constitutes a major reference point for France, as the members are predominantly former French colonies. And while the role of France has notably declined in the former colonies in West Africa (Médard 2005), Central Africa continues to constitute the less-studied heartland of French presence and influence.

What makes this case illustrative for a regional power from afar is that "the CFA is arguably the most blatant example of functioning neocolonialism in Africa today" (Taylor 2019: 1065). In addition to economic power, the case of France also illustrates the other primary means of power in international relations (Baldwin 2012: p. 275). Crucially, it is deemed to militarily behave akin to a regional power in some of its former colonies in Africa (Gaudino 2018: p. 84). Furthermore, the diplomatic presence and the influence in terms of culture and ideology are also pronounced. Identity building in the shape of a post-colonial paternalism has persisted as the backbone for the place that France and Central Africa attribute to themselves in the

\footnotetext{
1 See also Buzan and Wæver (2003: p. 243-244) who characterise Central Africa as an insulator zone.

2 From a topographic point of view, Central Africa would also cover parts of the Democratic Republic of the Congo and Angola as well as Sao Tome and Principe. From a political point of view, the regional organisation Economic Community of Central African States (ECCAS) also claims to represent Central Africa. However, its membership is considerably larger and fluctuating with several states not having been French colonies and today being more closely entangled with the Great Lakes or Southern Africa.
} 
world (Profant 2010). A sense of exclusive proximity, sustained by habitual informal and formal practices within a network of political, cultural, economic and security actors on both sides has been captured in the portmanteau word Françafrique (Bovcon 2013: p. 16). Initially used to stress commonality, the term contains a negative connotation of corruption and opaqueness since the 1990s. In particular, the massive fraud scandals and ensuing legal proceedings of the oil company Elf and of arms sales to Angola unveiled the widespread corruption networks tying African leaders to France. The scandals involved numerous political and business leaders and sensitised the French public and the judiciaries for the type of activities carried out in Africa. Together with the simultaneous death of key actors of Françafrique, in particular of the long-standing political advisor Jacques Foccart in 1997, the scandals marked a turning point. Political elites have tried to distance themselves from the term or similar ones such as pré carré (backyard) or chasse gardée (preserve). Presidents Sarkozy, Hollande and Macron repeatedly and explicitly claimed to have turned the page of Françafrique. ${ }^{3}$ Indeed, old structures have been dismantled and standards of compliance have been installed. Under the term biens mal acquis, civil society organisations have incited the judiciary to seize Central African assets due to embezzlement. Opposition to French military or financial involvement is also voiced more frequently, although with limited effect (Koddenbrock 2020: p. 525). Meanwhile, the French government seeks to disperse suspicions of unilateral involvement by formally acting upon demands from the African side in its military and economic operations. Yet, underneath the veneer of about-face in official discourse many informal networks persist (Chafer 2014). The networks are driven by a multitude of actors that mirrors the different dimensions of power projection: economic, political, diplomatic and military (Baldwin 2012: p. 275). The case of France in Central Africa thus illustrates a wide gamut of regional power, including interpersonal relations between politicians, military operations, commercial activities of private and public companies, financial flows and cultural narratives. Although the diversity of dimensions entails different and sometimes even contradicting objectives of how and for what purpose they should be projected, they often overlap in practice and jointly fuel the interdependence. Portals for such intersections are for instance the regular summits involving business and political leaders organised by Richard Attias (Carter 2018: p. 62). In sum, the case of France in Central Africa offers a multidimensional illustration for the analysis of powerhood.

In order to answer the research questions, the regional power framework will be comprehensively applied. The scholarship on regional powers offers an established way to measure and distinguish thresholds of power and identify the underlying mechanisms. Although scholars do not share the same emphasis regarding the most defining aspects of power, they broadly converge on a constellation that involves the congruence of three sets of criteria, which reflect the three main stages of the development of the field since 2010.

\footnotetext{
3 See for instance the speech of President Sarkozy for the 50th anniversary of independence of French colonies in Africa, in which he declared that France had left behind any colonial nostalgia (Reuters, 2010).
} 
The first set of criteria is concerned with identifying the status of a regional power through relevant properties. Typically, scholars rely on measuring the military and economic weight within a region, complemented with soft power elements. A regional power thus needs to have a paramount standing in these criteria, although there is no authoritative agreement on how large the share exactly needs to be (Cline et al. 2011). A specificity for external actors is that the measurement of power cannot rely on the total military or economic capacity but only on the capacity that is relevant to that region.

The second set of criteria is concerned with identifying the practices of a regional power to lead the region (Schirm 2010; Braveboy-Wagner 2016). In addition to having a substantial power share, a regional power needs to be willing to direct these resources into recurrent actions that ensure the assumption of a hegemonic or even imperial role. This can be traced through military interventions or preferential trade agreements. Another insightful way to identify such behaviour is to study regional organisations (Hulse 2016). Regional organisations can be effective channels of the most visible signs of hegemonic behaviour: the provision of regional public goods or the coercion of other members (Destradi 2010).

The third set of criteria is concerned with identifying the effect of a power on the region. In addition to having the relevant attributes and behaviour, a fully fledged regional power is deemed to require a regional followership (Malamud 2011). This can be studied through the behaviour of other members in regional organisations or in global arenas, which illustrates their reaction to the ascendance to regional power of one state. Another way is to look at the convergence of domestic policies with the regional power.

Taken together, these three sets enable a depiction of powerhood to order regional powers in different categories. The next section argues that France fulfils all three defining criteria of a regional power (Womack 2016; Burges 2008). It is in a dominant position in the region, actively seeks to maintain its centrality and has generated consensual followership. The main strategic difference with states that are located within the territorial delineation of the region is the greater necessity for legitimisation. An external actor cannot resort to a narrative of geographical determination by claiming for instance "African solutions to African problems" (Beswick 2010). The analysis will reveal that in turn, quasi-membership in regional organisations allows France to retain a position within rather than outside of regional governance structures.

\section{France's regional power capacity in Central Africa}

The following sections establish the regional power conditions that France fulfils in Central Africa and examines how France deals with the specific challenges of being an external regional actor. In line with the power measurements introduced in the previous paragraphs, the first criterion to establish whether France holds the status of a regional power in Central Africa is to examine the military and economic 
capacity, as well as its soft power (Cline et al. 2011). These capacities are not centralised in one single actor but rather dispersed among various private and public actors.

Military capacity constitutes the most crucial feature of a regional power according to realist thought and is considered to be a decisive factor to be able to enact a unilateral and coercive, i.e. imperial, regional strategy (Destradi 2010: p. 904). Although it has decreased in absolute terms over the past decades, France still maintains a substantial military presence in the region (French Ministry of Armed Forces 2021). Three hundred and seventy troops are stationed at the main permanent regional military base in Gabon, which has been established in the year of political independence in 1960. Other permanent but smaller bases are implanted throughout the region, for instance an air force base in N'djamena in Chad. A further 100 troops are embarked on a permanent maritime mission in the Gulf of Guinea. ${ }^{4}$ Moreover, the French operation Barkhane is directed at containing violent jihadism in the Sahel (Griffin 2016). Although Central Africa is not the primary destination, this operation extends to the Lake Chad which concerns Chad and Cameroon (French Ministry of Armed Forces 2017). Finally, France is also very present within the Central African armies, by detaching military advisers (Vallin 2015). Given that no Central African country holds a military base in the region and the USA have much less presence on the ground, France can be considered the leading regional military power.

Economic capacity constitutes the second key feature. Central Africa is a region that is weakly integrated in economic terms. All countries heavily depend on the export of natural resources, in particular oil, which entails a near-absence of intra-regional trade or regional value chains (UNECA 2020). In contrast to Central African countries, France is economically well established in the entire region. It ranks second after China for commercial exchanges, in particular for imports into the region (UN COMTRADE 2020) and French corporations such as Orange, Bolloré or Total are leading actors in key sectors (Chafer 2014). Even more striking is France's role in monetary terms. Central African countries share a common currency, the CFA Franc, which was fully convertible at a fixed rate determined by France to the French Franc until 2002, and has been fixed to its successor, the Euro, since. ${ }^{5}$ Central Africa has a regional central bank that is paradoxically not in charge of money supply and monetary policies, as these are primarily determined by the European Central Bank (ECB) along with the French government who guarantees the convertibility (Gulde and Tsangarides 2008). Thus, the CFA Central Bank merely acts as a transmission belt between France and the CEMAC members. The board is constituted by both French and Central African representatives. France also holds an Operations Account for the CFA, which requires the Central African governments to deposit at least $65 \%$ of their reserves with the French Treasury.

\footnotetext{
4 This mission does not fully correspond to the delineation of Central Africa used in this paper since it also covers waters adjacent to West African countries and Sao Tome and Principe.

5 A second CFA zone exists in West Africa under the acronym UEMOA. It formally has its own central bank and currency. Since the economic set-up of the two zones, including exchange rates, is almost identical, they are often lumped together and considered as one, together with the Comoros, which have a similar arrangement with France. For the purpose of this paper, only the Central African CFA zone is considered.
} 
These funds are unilaterally managed and invested by the French government, who pays out a fixed interest rate to Central African countries, accounted for as development aid (Nubukpo et al. 2016). Given the paramount commercial and monetary role of France in Central Africa, the country can be considered the leading regional economic power. Other external actors - China in particular but to a lesser degree also countries such as Turkey, Russia, Egypt and Morocco- have increased their economic ties with and presence in Central Africa with numerous private and public companies being engaged in mining and infrastructure. However, the monetary power of France, which provides a fixed-rate convertibility and thus a substantial advantage to French companies operating in the region, remains unchallenged.

Soft power constitutes the third key status indicator for regional powers. Its analytical vagueness has made it difficult to operationalise in a systematic manner. However, France ranks highly in many recurrent indicators. Alongside Addis Ababa, Paris was the only destination that could be reached directly by air from all Central African capitals in 2019. Although regional connections exist, they operate with less capacity and frequency or require transfers in airports outside of the region (Flight Connections 2020). France has embassies and schools in all countries and plays a central role for the foreign policy of the countries in the region. Most presidents in the region do not frequently travel abroad, but Paris remains a favourite destination for the sparse state visits. For instance, the Cameroonian President Paul Biya has been received three times by his French counterpart Emmanuel Macron (Presidency of the Republic of Cameroon 2020). France is by far the main destination for migrants from the region, in particular for tertiary students seeking to attend university abroad (UNICEF 2021). Finally, all Central African countries are members of the Francophonie and adhere to the standards provided by the French Academy. The former Spanish colony Equatorial Guinea introduced French as an official language, even though its use is marginal. In terms of education, language, diplomacy and prestige, France thus wields more soft power in Central Africa than any other country of the region, and despite the growing efforts of countries like China to provide friendship symbols and increase education links as part of their official diplomacy, it remains the main regional power in this regard.

In sum, France holds high levels of both soft and hard power (Faleg and Palleschi 2020: p. 44) and thus the hegemonic capacity for a regional power, as defined by Alden and Schoeman (2015). Power is exercised by diverse actors that do not necessarily proceed jointly, such as the armed forces and finance officials, but that contribute to the power capacity of France in the region. The stability of the asymmetric structure is also facilitated by the relative weight of Central Africa: the CEMAC region has less population than France, and its GDP merely represents 3\% of the French economy (World Bank 2021).

\section{France's regional power behaviour in Central Africa}

The second criterion to establish whether France holds the status of a regional power in Central Africa is to examine its behaviour, in particular whether it is transforming its power capacities into leadership practices. 
In military terms, the CAR provides the most relevant case for a regional conflict. ${ }^{6}$ Over the past 25 years, the country has been the setting of several violent clashes that triggered a series of international military interventions, starting with the inter-African mission to monitor the implementation of the Bangui agreements in 1997 (Mbadinga 2001), when France still had a permanent base in the country. In this mission and in the various subsequent ones that were either organised unilaterally by France or in a multilateral cooperation with the United Nations and/or the European Union, France has played a key role by regularly providing the lion's share of troop contribution and other means but also in filling high-level positions (Welz 2016). In addition, France is actively contributing to maintain incumbents in power and is willing to intervene militarily when it feels that the regional order it promotes is endangered (Charbonneau 2008), most visibly in February 2019 with airstrikes knocking down armed opposition groups in Chad (The Economist 2019) and in legitimising the military junta after the death of Idriss Déby in April 2021. France is actively assuming the role of the main stability provider in the region by containing violent crises, which persist in five out of six countries (HIIK 2020) to ensure regime continuity and geopolitical status (Gegout 2018).

In economic terms, the CFA zone illustrates how France is using its status to actively foster regional hegemony. When the French Franc was replaced by the Euro, the European Central Bank (ECB) technically inherited the power from France to determine the monetary policies of the CFA zone (Bach 2015). However, the ECB has avoided an active role (Gulde and Tsangarides 2008). It considers itself a technical institution and is thus not at ease with a primarily political arrangement. For the ECB, the pegging is the responsibility of Central African governments and thus constitutes an arrangement that is tolerated but unsolicited. The ECB refers to its formal mandate which is to devise monetary policies for Eurozone members. It does not question France's prerogative and does not conduct any assessment of the impact it has in Central Africa. ${ }^{7}$ Although France cannot solely determine the ECB's monetary policies, it continues to control the rest of the CFA arrangement. France is also willing to make concessions that enhance the stability of the regional order in order to sustain the power balance. In December 2019, France decided to reform the West African part of the arrangement by renaming the currency from Franc to Eco, by dissolving the Operations Account and by withdrawing its board members (Amato and Nubukpo 2020). This does not yet apply to Central Africa, but similar changes have been floated. While the most visible imperial elements of the arrangement might eventually fade out, essential elements of hegemonic power structure remain intact (Bieler and Morton 2004). France's power to fix the exchange rate and guarantee the convertibility is not altered by the reform plans.

\footnotetext{
${ }^{6}$ The conflict in the CAR is not merely a national issue but has a regional dimension. Although the main intervention occurred inside the country, the conflict itself and the international interventions have had a cross-border dimension, in particular towards Chad. More importantly, regional organisations have orchestrated regional responses, initially CEMAC and over time increasingly ECCAS.

${ }^{7}$ Interview by the author with two senior ECB staff in October 2019 in Frankfurt (Germany).
} 
While France does not intervene in each and every regional policy area, the country thus remains actively involved in the two main domains used to define regional powers (Gilpin and Gilpin 2001). France is able to devise and implement strategies to shape the regional economy and security in Central Africa. The government is willing to dedicate the available resources to diplomatic, military, cultural and commercial activities, allowing it to fulfil a regional power status (Milani et al. 2017; Volgy et al. 2017). French development aid privileges Central Africa despite the relatively small population size (AFD 2018). In 2018, 700 mil. Euro, i.e. almost $20 \%$ of French aid to Africa, was disbursed to Central Africa (OECD 2020). There is also a self-understanding among the French ruling elite of the leading role their country should play in Central Africa. As Lopez Lucia (2015) argues, reliable narratives are crucial elements to enable a powerful state to assume the role of regional power, and while the term power is not directly evoked, there is recurrent reference to leadership when Frances pictures itself in Africa (French Senate 2013). Since Central Africa does not pose an immediate security threat to France, discourses stress structural and historic continuity. Combined with the use of a wide range of foreign policy instruments, this narrative allows for an effective implementation. In this sense, France's status preservation in Central Africa is akin to Russia's inward focused approach in the post-Soviet space, in particular in the Eurasian Economic Union (EAEU) (Kirkham 2016). The hard and soft power that has been accumulated during and after colonisation is deliberately used to sustain hegemony in the region. The practices of military and economic power partly follow specific logics linked to domestic French interests, but they converge in the broader rationale of stabilising the allied political elites in power. The prevailing exercise of regional power is hegemony, although in line with Destradi (2010) the readily use of military power adds an imperial dimension.

\section{Perception of France as a regional power in Central Africa}

The third criteria to establish whether France holds the status of a regional power in Central Africa is to examine the effect of its status and actions on the region, in particular whether it is perceived and accepted as a regional power (Schirm 2010; Malamud 2011).

Although Central Africa is weakly integrated, there are particularities shared by most if not all countries. All presidents are authoritarians and have been in power for on average for over 20 years (average figure in August 2021, including the military junta in Chad). In several instances, presidencies have been hereditary. Elections are not fulfilling democratic standards, and political opposition is oppressed. All countries rank at the bottom of the Freedom House report and are considered "not free" (Freedom House 2020). Consequently, Central Africa is a region where political leaders are preoccupied with perpetuating their regime and are averse to any change that could challenge their rule. The regional power of France is conducive, as it provides stability and privileges incumbents.

The situation thus reflects a consensual variation of hegemony, where the main interests of the involved parties are embedded into the governance of the regional 
order (Burges 2018: p. 195). Hegemony is not occurring against the will of local elites but thanks to their active contribution. Rather than being bystanders, they pursue an inside-out approach, in which they induce an external actor to support their position (Pace et al. 2009). French hegemony provides them with opportunities to make private gains, for instance through capital flight, and to ensure regime survival. In addition, Central African governments can improve their domestic and international standing by making France part of their regional arrangements. The CFA zone illustrates well how both sides actively contribute to the situation. The participation of the presidents of Central Africa in prolonging and reproducing the hegemonic relationship is crucial. By not claiming monetary sovereignty but rather actively supporting the externalisation of their currency, the political elite legitimises the CFA and contributes to its longevity. The CFA zone provides a stable currency that curbs inflation and grants international recognition (Nubukpo 2007). In addition, it also provides opportunities for personal profits. The CFA Franc is considered to be a substantially overvalued currency (IMF 2019). This provides advantages for exporters of capital and importers of goods. In practice, Central African elites are the main beneficiaries of a high purchasing power vis-à-vis the Euro, together with the Eurozone companies repatriating profits or providing services for upper and middle classes. French oil companies have played a key role in combining extractive activities with corruption (Chafer 2005). Affluent Central Africans, led by neo-patrimonial politicians, use the CFA to freely transfer their wealth to France and the Eurozone. This constellation reflects what Bayart and Ellis (2000) conceptualised under extraversion: a situation where African elites actively contribute to a hegemonic relationship for personal interests. The consensus to French hegemony is thus not based on a widespread popularity among citizen but generated by a relatively small group of direct beneficiaries, for which is does constitute a problem but rather a resource (Peiffer and Englebert 2012).

The CFA - as well as the Cotonou Agreement that links France's former colonies to the European common market - are not primarily determined by economic necessity but by political considerations (Kotsopoulos and Mattheis 2018). One of the main theoretical motivations of having a regional currency or a trade agreement is to lower transaction costs between economic actors. However, Central Africa scores very low with respect to intra-regional trade, infrastructure and productive integration (UNECA 2020: p. 24). In addition, the weak state of the private sector in Central Africa implies that there is little active demand for a regional currency (African Development Bank 2019). One could argue that a regional currency is an instrument to trigger structural economic change, but without corresponding economic measures, such as the fostering of regional industries and value chains, this does not seem to be the primary motivation.

France also generates followership by sustaining the longevity of political rule with military protection. The 2019 French intervention in Chad occurred at the demand of the Chadian President who feared armed opposition to his rule and President Emmanuel Macron was invited as the guest of honour at his funeral in 2021 (DW 2021). Although the French government considers itself a global advocate for human rights and democracy, this commitment is not discernible in its own sphere of influence. Despite their authoritarian rule, Central African elites seldom 
fall into disgrace with the French government, and their misrule is only exposed by civil society or judges (Perdriel-Vaissière 2017). France is thus not prioritising rule of law concerns or being particularly assertive concerning democratic values. It does not impose sanctions for oppressive rule; however, it is more likely to act upon deviation from the regional order. Central African states are aware that to that end France can rely on almost the full arsenal of hegemonic sanctions, from revoking trade agreements to cancelling foreign aid or even intervening militarily (Ikenberry and Kupchan 1990).

Central African leaders are particularly sensitive to symbolic recognition from the regional power to boost their domestic status. For instance, Equatorial Guinea requested French regiments to participate in its national parade (Macron 2018) and presidential summitry with France is a central pattern (Faleg and Palleschi 2020: p. 18). France also remains a personal point of reference for the political elite. All presidents have earned a degree in France, except for Obiang from Equatorial Guinea, whose family has however held substantial assets in Paris. ${ }^{8}$ Central African states recognise the power status of France within their region by ascribing it a central position in their cultural reference and diplomacy, thus solidifying its status (Paul et al. 2014).

Domestic political oppression in central Africa also means that anti-imperial criticism of France is very limited. Unlike in West Africa, the CFA and Françafrique have not been seriously challenged domestically. Within the region, there is a lack of contenders to regional power that could spur a counter-hegemonic movement (Lemarchand 2009). Central African statehood remains too frail to openly contest France, in particular since political elites are co-opted by private gains (Bussmann and Oneal 2007). Central African states are also mired with internal instability, which undermines their capacity to project power within the region, as Adebajo and Landsberg (2003) and Schoeman (2015) argued. Cameroon might have a larger power share in the region in relation to its neighbours, which for instance translated in the country nominating the secretary general of CEMAC during decades (Mattheis 2017). However, its power is mainly exercised in a sub-hegemonic rather than counter-hegemonic manner (Meyer 2011).

The perception and acceptance of France as a regional power are also contingent on other external actors (Nolte 2010). The other four permanent members of the UN Security Council have supported the leadership of France in the CAR conflict (UN Security Council 2013). The USA maintain two permanent military bases in the region in Gabon and in Chad. However, they seek a light footprint that concentrates on training, drones and intelligence and financially support France's more invasive engagement (Rye Olsen 2017). The USA also respect the prerogative of France in the CAR, though they remain present in the Gulf of Guinea due to oil interests (Metelits 2016). China is the external actor that has most substantially increased its presence in the region and is thus acquiring significant power means. For Central Africa, the primary

\footnotetext{
8 A villa worth over 100 mil. Euro worth plus a collection of luxury cars held by Teodorin Obiang, VicePresident and son of the President of Equatorial Guinea, were seized by a French court in a corruption case (Chrisafis 2017).
} 
power dimensions are political, financial and economic, as the Chinese military focus in Africa is more oriented towards East Africa. The main links thus involve loans, commercial activities and diplomatic engagements. As a consequence, the status of France is decreasing. However, this primarily affects bilateral and continental relations. The main Chinese multilateral instruments - the Belt and Road Initiative and the Forum on China-Africa Cooperation - are not aimed at holding central Africa together as a region (Ehizuelen 2017). China is thus becoming a notable power in Africa at large and in individual countries but less so as a regional power in Central Africa. Lastly, Russia also developed a noteworthy presence in Central Africa, both in the economic sector of natural resources and in military cooperation. It ranks well below France in terms of power share but defies the regional dominance in two ways. First, state-backed private military groups operate in the Central African Republic, where a Russian military basis is planned and the national security advisor of the President is Russian, thus challenging the predominance of France in the country (Marten 2019; Towfigh Nia 2020). Second, Russia is able to provide incumbent support to authoritarian presidents under domestic pressure, which is a key concern of Central African leaders and replicates the Russian backing of presidents in Central Asia (Tolstrup 2015). Through these practices that involve opaque networks and blurred lines between private and public actors, Russia is evocative of the original Françafrique. It could therefore significantly alter the extraversion portfolio of the CAR, which would make it less dependent on France for regime survival. However, this shift for now remains within a bilateral logic that does not involve the establishment of an entire region being held together through its interdependence with Russia.

Among the neighbouring states of Central Africa, only Nigeria stands out as a potential aspirant. However, the country has not directed its capacities towards Central Africa and is primarily concerned with domestic or West African issues (Bach 2007). Similarly, South Africa has only ephemerally played a role in the regional order. The existing African discontent about France's hegemonic position is channelled via the African Union (AU), who has explicitly refused to formally recognise CEMAC as a regional pillar of continental integration and privileges ECCAS instead. However, the AU has been shying away from open confrontation with France, even in the face of existing overseas territories, which have even expanded with Mayotte becoming a French département in 2011.

In sum, France is not only a de facto regional power but is also recognised as such by both internal and external actors. Local elites astutely foster the inclusion of France in the region to secure regime stability and private gains. From the outside, actors such as Russia and China challenge the power of France in Central Africa but not to the point of replacing it as a regional power. The prerogative of France as belonging to the region remains internationally accepted, and is visible in any outside initiative towards the region. No multilateral endeavour would circumvent France, be it the EU and the International Monetary Fund regarding the CFA or the AU and the United Nations regarding conflict resolution in the CAR. 


\section{French quasi-membership in Central African governance structures}

Having confirmed France's status as a regional power leads to the second question guiding this paper: how does France overcome geographical distance in order to effectively act as a regional power? Regional power based on consensual hegemony cannot only rely on unilateral action but also entails a multilateral engagement (Prys 2010). Concepts of regional power generally include influence or control over a regional governance structure (Hulse 2016). Regional powers are able to steer if not dominate the regional organisations they are a member of. They can influence the staffing of top positions, the geographical delineation and the institutional model. In case of dissatisfaction with the status quo of regional governance, they gather followers for the creation of new regional organisations that match their preferences. However, research on regionalism and on regional powers has operated with a restricted understanding of membership. Most approaches study regional integration as a project led by internal actors (Laursen 2018; Mattli 1999). Research on interregionalism has dealt with how external actors, the EU in particular, have tried to shape and construct regions, but these actors have been considered as entirely separate outsiders (Söderbaum and Stålgren 2010; Baert et al. 2014; Mattheis and Wunderlich, 2017). Although it is not formally listed as a member by CEMAC, France wields similar or even more influence in the organisation than the formal member states. It provides financial backing and staff, determines crucial policy fields and is engaged in a permanent manner. Most importantly, by guaranteeing the exchange rate, France provides a regional public good and thereby acts as a regional power in the regional organisation (cf. Hulse 2016). Although France does not enjoy the same formal status as other members, CEMAC would struggle to perform its functions without France, in particular the constant capital outflow. De jure membership is thus subverted by de facto control, which is akin to quasi-membership. Söderbaum (2013: p. 6) has argued that regional organisations are "surface phenomena" of regionalism. They are thus not autonomous but depend on the underlying regional order. In the case of Central Africa, CEMAC is indeed mirroring the regional power constellation rather than being an independent region-building actor. The practices of bureaucrats and diplomats managing the organisation are primarily reproducing the existing hegemony pattern centred on France (cf. Larner and Walters 2002). The role of CEMAC in this context is to politically legitimise this hegemony (cf. Barnett and Finnemore 2004). Imperialism is also evident in the lack of reciprocity. It is not foreseen that Central African actors become actively involved in any French or European affairs.

CEMAC thus provides a wide range of institutional functions that explains postcolonial hysteresis (Bach 2015: p. 16), i.e. the endurance of a monetary institution that would otherwise have lost its purpose given the rise of Pan-Africanism or the introduction of the Euro. CEMAC binds the regional power as a de facto member to the region. Moreover, it constitutes a central element of consensual hegemony, as it provides legitimacy to the regional order and extraversion opportunities. This explains why political elites in Central Africa do not oppose the arrangement but rather seek to involve France inside the region to their own advantages. In exchange, CEMAC allows France to frame its power as the pursuit of collective objectives, 
even though they are not carried by a large consensus of the wider population. These objectives are solely legitimised by political elites in an autocratic environment and the regional organisation provides a narrative that allows to claim representation for Central African societies at large. The existence of a regional organisation also helps to shield the region against other external influence. It can for instance delegitimise military interventions by other external actors or impede economic agreements. In the same vein, CEMAC weakens overlapping regional projects, in particular ECCAS (Meyer 2011). The underlying identity for the hegemonic constellation undermines other regional ideologies such as Pan-Africanism.

Closer to home, France also resorts to regional organisations to amplify its power in Central Africa. Part of its capacity to shape the regional order in Central Africa derives from being part of the European Union, which also possesses the capacity and willingness to influence the region through development aid and trade agreements (Carbone 2013). Although the policies of the two actors are not always fully in line, France is the uncontested leading EU member in Central Africa and benefits from European followership in both economic and military terms (Mattheis 2021). The ECB gives the CFA more clout, and EU members provide additional troops for France-led interventions, such as Portugal in the CAR. France's engagement as a regional power in Central Africa does thus not require a disengagement from its immediate region, i.e. the EU. On the contrary, it is fully embedded within European integration.

France does hence not pursue a purely imperial strategy but a hegemony that is embedded in a consensus-generating multilateral setting in the EU and-even more important-in CEMAC. Becoming a quasi-member of a regional organisation represents a relevant strategy for an external member such as France to legitimise and exercise its power within the region.

As of now, France has been highly successful in maintaining a hegemonic structure that is institutionally reproduced. Yet, the asymmetry of France's regional power does not entail almightiness and achieving every self-interest. Regional orders allow for spaces of counter-hegemony that less powerful actors may use for their own objectives or even to subvert dominance (De Oliveira 2007). Overlapping regional organisations, such as ECCAS or the AU, provide potential arenas for coalition building of weaker states, as other cases such as Central Asian countries in the EAEU have indicated (Gast 2017). The reform process of the CFA zone also provides opportunities for internal and external actors to reduce France's share of power in the region (Giorgioni 2019). Hegemons are usually considered as beneficial for peace and stability in a regional order (Nye 2004). A decline of France's regional hegemony in the future would thus entail an increase in regional instability, as it could lead to regime change and even a reconfiguration of boundaries. This would be a daunting prospect for the regional political elites who have sought to prevent such upheavals precisely by adhering to consensual hegemony. 


\section{Conclusions: A regional power from afar}

In conclusion, the first research question whether France constitutes a regional power in Central Africa can be answered affirmatively: France fulfils all three defining criteria of regional power (Womack 2016; Burges, 2015): it is in a dominant position in the region, actively seeks to maintain its centrality and has generated consensual followership. France is hegemonic with respect to monetary control, regime support and regional governance institutions. This hegemony, which combines imperialism and consensus building, forms the basis of regional power (Destradi 2010: p. 917). Despite being an external actor, France constitutes a regional power in Central Africa for all intents and purposes, be it capacity, willingness or recognition (Cline et al. 2011). On the core regional power criteria that France relies on-military and monetary power plus regional elite consensus-other external powers have not been able to fundamentally reduce France's power share. Central Africa is hence a region centred on one powerful state- a specific but stable constellation of regional order (Hurrell 2007).

The second research question concerned how geographic distance is overcome for France to wield and exercise regional power. Most visibly, the territorial gap is bridged through a diplomatic, economic, cultural and military presence on the ground. France also offers political elites an economic and security system that provides regime stability and personal gains. Crucially, regional governance structures play a central role in keeping the system running and providing it with legitimacy. As Lopez Lucia (2015) contended, not every powerful state seeks to dominate or lead a regional organisation. For France however, it is crucial in order to make up its distance. France might not be a formal member of CEMAC, but it has established a quasi-membership that allows it to institutionalise economic, cultural and security dominance (Linklater 2005). The reproduction of hegemony through quasi-membership rests on a cumulative process based on colonialism and on the Françafrique consensus (Charbonneau 2014). As a quasi-member, France is able to enact and justify a wide array of hegemonic and imperial strategies to enable the attainment of its own objectives, including economic gains and geopolitical status (Wigell 2016). The status allows France to participate in decision-making processes about regional security and economics. Rather than a negotiation between Central Africa as a region on one side and France as an external state on the other side, Central African issues are jointly managed, with France enjoying a privileged position. Quasi-membership is not a phenomenon limited to this specific case. Other regional organisations are used in this manner to enhance a power status in distant regions. For France, this applies to the West African CFA zone and the G-5 Sahel. Moreover, there are also cases where quasi-membership is formalised, for instance the Indian Ocean Commission, where France has acquired full membership through its overseas territories (Bouchard and Crumplin 2011). The African Development Bank or the Inter-American Development Bank also provide so-called non-regional members with a formal status that includes voting rights and staff quotas. 


\section{Implications for the study of regional powers}

Beyond providing answers to the main research questions, the case study also points to two limitations of the regional power framework. First, a change of the regional delineation might yield different power constellations. Several valid interpretations of who belongs to Central Africa exist. For instance, ECCAS represents an alternative regional arrangement with a pan-African background. Power shares would shift even more by applying larger regional containers such as sub-Saharan Africa. In addition, if other external actors such as Russia and China develop a substantial power capacity in the region, the relative power distribution needs to be dynamically reassessed. Second, this paper remained within a state-centric understanding of regional powers. Yet, non-state actors also play an important role in defining a regional order. France itself is a composite actor of private and political elites, weaving in European supranational institutions. To paint a complete picture of regional power in Central Africa, a more systematic inclusion of armed groups such as factions of Boko Haram or business corporations such as the oil company Total would be required. It is also conceivable that regional and international organisations acquire sufficient actorness and institutional capacity to gain substantive shares of regional power. For instance, the EU could further absorb France's hegemony by intervening in the monetary arrangement of the CFA or overseeing military engagements in Central Africa.

In terms of implications for the broader scholarship, the shift away from a topographically restrictive understanding of region does not entail a fundamental revision of the definition of regional powers but implies an application of the concept beyond BRICS and MINT. Regions hitherto considered void of regional powers should be re-examined by considering the potential existence of external powers. This perspective also reinforces the argument that regional power is a status that can be held by the same actor in several regions, as has been in particular explored with reference to Turkey (Parlar Dal 2016). Conversely, a region can harbour more than one regional power, in which case regional hegemony is distributed along several nodes (Womack 2016). This would also be applicable to a multiplicity of external actors, if several of them hold substantial power over a region.

Even if one were to reject the notion of regions being socially constructed, the study of external powers in some cases also involves physical presence. In addition to military bases, external powers can hold overseas territories. For instance, with over 3.000 troops stationed in French territories in South America and the Caribbean in areas, France has an inevitable impact on the regional power distribution (French Ministry of Armed Forces).

While the assessment that France wields significant power in Central Africa will be hardly surprising to observers of the region, assigning the status of regional power has important implications. This article contends that France is not merely an external great power: it is constitutive of the region. This implies that being a power from afar is not necessarily ephemeral or limited to a specific issue area. The permeability of regions towards external actors has already been extensively demonstrated with respect to other regions, for instance West Africa, where both France and the USA actively shape transnational security structures (Bagayoko-Penone 2004). 
This paper goes a step further and argues that geographically distant actors can be so intrinsically weaved into region-building processes that they cease to be purely extra-regional. As the case of France illustrates, a distant actor can shape a region from the inside. In particular, the involvement in CEMAC shows that through substantive immersion external actors can be actual insiders of a regional organisation and thus need to be considered as quasi-members. The exercise of power is evident in unilateral actions, such as military interventions, but multilateral strategies are crucial for the narrative and legitimacy of regional leadership, especially when exercised from afar. Crucially, being a distant regional power requires local agency in the shape of political elites that actively embed the external actor within the region and its governance and extraversion mechanisms. Taking into account the actual distribution of regional power also addresses the exacerbated focus on formal status in regional organisations (Lopez Lucia 2018). Scholars of Comparative Regionalism need to scratch beyond the surface of regional organisations, now that the boundary lines between outsiders and insiders regarding regional power are being unpacked and revised.

Acknowledgement This article is dedicated to the late Ian Taylor - a much valued mentor and friend who generously took the time to talk over imperialism and neocolonialism in francophone Africa while I was writing the first draft.

Funding Open Access funding enabled and organized by Projekt DEAL.

\section{Declarations}

Conflict of interest The author states that there is no conflict of interest.

Open Access This article is licensed under a Creative Commons Attribution 4.0 International License, which permits use, sharing, adaptation, distribution and reproduction in any medium or format, as long as you give appropriate credit to the original author(s) and the source, provide a link to the Creative Commons licence, and indicate if changes were made. The images or other third party material in this article are included in the article's Creative Commons licence, unless indicated otherwise in a credit line to the material. If material is not included in the article's Creative Commons licence and your intended use is not permitted by statutory regulation or exceeds the permitted use, you will need to obtain permission directly from the copyright holder. To view a copy of this licence, visit http://creativecommons.org/licen ses/by/4.0/.

\section{References}

AFD. 2018. Towards a world in common: AFD group 2018-2022 strategy. Paris: AFD Group.

Adebajo, A., and C. Landsberg. 2003. South Africa and Nigeria as Regional Hegemons. In From cape to cairo: Southern Africa's evolving security challenges, ed. M. Baregu and C. Landsberg. Boulder: Lienne Rienner Publishers.

African Development Bank. 2019. Central Africa economic outlook 2019. Abidjan: AfDB Group.

Alden, C., and M. Schoeman. 2015. South Africa's symbolic hegemony in Africa. International Politics 52 (2): 239-254.

Amato, M., and K. Nubukpo. 2020. A new currency for West African States. PSL Quarterly Review 72 (292): 3-26. 
Bach, D.C. 2007. Nigeria's "manifest destiny" in West Africa: Dominance without power. Afrika Spectrum 42 (2): 301-321.

Bach, D.C. 2015. Regionalism in Africa: Genealogies, institutions and trans-state networks. London: Routledge.

Baert, F., T. Scaramagli, and F. Söderbaum. 2014. Introduction: Intersecting interregionalism. In Intersecting interregionalism, ed. F. Baert, T. Scaramagli, and F. Söderbaum, 1-12. Dordrecht: Springer.

Bagayoko-Penone, N. 2004. Afrique: Les stratégies française et américaine. Paris: Editions L'Harmattan.

Baldwin, D.A. 2012. Power and international. In Handbook of international relations, ed. W. Carlsnaes, T. Risse, and B.A. Simmons, 273-297. London: Sage.

Barnett, M., and M. Finnemore. 2004. Rules for the world: International organizations in global politics. Ithaca: Cornell University Press.

Bayart, J.F., and S. Ellis. 2000. Africa in the world: A history of extraversion. African Affairs 99 (395): 217-267.

Beswick, D. 2010. Peacekeeping, regime security and 'African solutions to African problems': Exploring motivations for Rwanda's involvement in Darfur. Third World Quarterly 31 (5): 739-754.

Bieler, A., and A.D. Morton. 2004. A critical theory route to hegemony, world order and historical change: Neo-Gramscian perspectives in international relations. Capital \& Class 28 (1): 85-113.

Bouchard, C., and W. Crumplin. 2011. Two faces of France: 'France of the Indian Ocean'/'France in the Indian Ocean.' Journal of the Indian Ocean Region 7 (2): 161-182.

Braveboy-Wagner, J., ed. 2016. Diplomatic strategies of nations in the global south: the search for leadership. New York: Springer.

Burges, S.W. 2015. Revisiting consensual hegemony: Brazilian regional leadership in question. International Politics 52 (2): 193-207.

Bussmann, M., and J.R. Oneal. 2007. Do hegemons distribute private goods? A test of power-transition theory. Journal of Conflict Resolution 51 (1): 88-111.

Buzan, B., and O. Wæver. 2003. Regions and powers: The structure of international security. Cambridge: Cambridge University Press.

Börzel, T.A., L. Goltermann, and K. Striebinger, eds. 2016. Roads to regionalism: Genesis, design, and effects of regional organizations. London: Routledge.

Bovcon, M. 2013. Françafrique and regime theory. European Journal of International Relations 19 (1): 5-26.

Brosig, M. 2021. Has BRICS lost its appeal? The foreign policy value added of the group. International Politics Online first. https://doi.org/10.1057/s41311-021-00327-y.

Carbone, M. 2013. Between EU actorness and aid effectiveness: The logics of EU aid to Sub-Saharan Africa. International Relations 27 (3): 341-355.

Carter, B.L. 2018. The rise of kleptocracy: Autocrats versus activists in Africa. Journal of Democracy 29 (1): 54-68.

Chafer, T. 2005. Chirac and 'la Francafrique': No longer a family affair. Modern \& Contemporary France 13 (1): 7-23.

Chafer, T. 2014. Hollande and Africa policy. Modern \& Contemporary France 22 (4): 513-531.

Charbonneau, B. 2008. Dreams of empire: France, Europe, and the new interventionism in Africa. Modern \& Contemporary France 16 (3): 279-295.

Charbonneau, B. 2014. The imperial legacy of international peacebuilding: The case of francophone Africa. Review of International Studies 40 (3): 607-630.

Chrisafis, Angelique. 2017. Son of Equatorial Guinea's president is convicted of corruption in France. The Guardian.

Cline, K., P. Rhamey, A. Henshaw, A. Sedziaka, A. Tandon, and T.J. Volgy. 2011. Identifying regional powers and their status. In Major powers and the quest for status in international politics, ed. T.J. Volgy, R. Corbetta, K.A. Grant, and R.G. Baird, 133-157. New York: Palgrave Macmillan.

Destradi, S. 2010. Regional powers and their strategies: Empire, hegemony, and leadership. Review of International Studies 36 (4): 903-930.

DW. 2021. Why France is backing Chad's new leader, Mahamat Idriss Deby. 23 April. https://www.dw. com/en/why-france-is-backing-chads-new-leader-mahamat-idriss-deby/a-57316728. Accessed 29 July 2021.

Droz-Vincent, P. 2007. Vertiges de la puissance: Le moment américain au Moyen-Orient. Paris: Editions La Découverte. 
Ehizuelen, M.M.O. 2017. More African countries on the route: The positive and negative impacts of the Belt and Road Initiative. Transnational Corporations Review 9 (4): 341-359.

Faleg, G., and C. Palleschi. 2020. African strategies: European and global approaches towards subSaharan Africa. Paris: EUISS.

Fawcett, L. 2004. Exploring Regional Domains: A Comparative History of Regionalism. International Affairs 80 (3): 429-446.

Fawn, R. 2009. "Regions" and their study: Wherefrom, what for and whereto? Review of International Studies 35 (5): 5-34.

Flight Connections. 2020. https://www.flightconnections.com/. Accessed 29 July 2020.

Frazier, D., and R. Stewart-Ingersoll. 2010. Regional powers and security: A framework for understanding order within regional security complexes. European Journal of International Relations 16 (4): 731-753.

French Ministry of Armed Forces. 2017. Revue stratégique de défense et de sécurité nationale. Paris: Ministère des armées.

French Ministry of Armed Forces. 2021. Carte des déploiements opérationnels des forces armées françaises. https://www.defense.gouv.fr/operations/rubriques_complementaires/carte-des-operationset-missions-militaires. Accessed 29 July 2021.

Gast, A.S. 2017. Regionalism in Eurasia: Explaining authority transfer to regional organizations. KFG Working Paper Series, No. 82. Berlin: Freie Universität Berlin.

Gaudino, U.M. 2018. Françafrique, a reluctant hegemony? Geopolitical Report 4 (2018): 83-101.

Gegout, C. 2018. Why Europe intervenes in Africa: Security prestige and the legacy of colonialism. Oxford: Oxford University Press.

Gilpin, R., and J.M. Gilpin. 2001. Global political economy: Understanding the international economic order. Princeton: Princeton University Press.

Giorgioni, G. 2019. The CFA Franc zone: A political re-evaluation twenty years after the advent of the Euro. Journal of Contemporary African Studies 37 (4): 379-403.

Griffin, C. 2016. Operation barkhane and boko haram: French counterterrorism and military cooperation in the Sahel. Small Wars \& Insurgencies 27 (5): 896-913.

Gulde, M.A.M., and M.C.G. Tsangarides. 2008. The CFA franc zone: Common currency, uncommon challenges. Washington, D.C.: International Monetary Fund.

HIIK. 2020. Conflict barometer 2019. Heidelberg: Heidelberg Institute for International Conflict Research.

Hanau Santini, R. 2017. A new regional cold war in the middle east and north Africa: Regional security complex theory revisited. The International Spectator 52 (4): 93-111.

Hettne, B. 2005. Beyond the 'new'regionalism. New Political Economy 10 (4): 543-571.

House, Freedom. 2020. Freedom in the world 2020. Washington, DC: Freedom House.

Hulse, M. 2016. Regional powers and leadership in regional institutions: Nigeria in ECOWAS and South Africa in SADC. KFG Working Paper Series, 76. Berlin: Freie Universität Berlin.

Hurrell, A. 2007. One world? Many worlds? The place of regions in the study of international society. International Affairs 83 (1): 127-146.

IMF. 2019. Central African economic and monetary community (CEMAC): Staff report on the common policies in support of member countries reform programs. IMF Country Report No. 19/383. Washington, D.C.: International Monetary Fund.

Ikenberry, G.J., and C.A. Kupchan. 1990. Socialization and hegemonic power. International Organization 44: 283-315.

Katzenstein, P.J. 2005. A world of regions: Asia and Europe in the American imperium. Ithaca: Cornell University Press.

Kirkham, K. 2016. The formation of the Eurasian economic union: How successful is the Russian regional hegemony? Journal of Eurasian Studies 7 (2): 111-128.

Knudsen, O.F., ed. 2017. Security strategies, power disparity and identity: The Baltic Sea region. London: Routledge.

Koddenbrock, K. 2020. Hierarchical multiplicity in the international monetary system: From the slave trade to the Franc CFA in West Africa. Globalizations 17 (3): 516-531.

Kotsopoulos, J., and F. Mattheis. 2018. A contextualisation of EU-Africa relations: Trends and drivers from a reciprocal perspective. South African Journal of International Affairs 25 (4): 445-460.

Lake, D.A., and P.M. Morgan. 2010. Regional orders: Building security in a new world. University Park: Penn State Press. 
Larner, W., and W. Walters. 2002. The political rationality of" new regionalism": Toward a genealogy of the region. Theory and Society 31 (3): 391-432.

Laursen, F., ed. 2018. Comparative regional integration: Theoretical perspectives. London: Routledge.

Le Gouriellec, S. 2018. Regional power and contested hierarchy: Ethiopia, an 'imperfect hegemon'in the Horn of Africa. International Affairs 94 (5): 1059-1075.

Lemarchand, R. 2009. The dynamics of violence in central Africa. Philadelphia: University of Pennsylvania Press.

Lemke, D.W. 2002. Regions of war and peace. Cambridge: Cambridge University Press.

Lemke, D.W. 2010. Dimensions of hard power: Regional leadership and material capabilities. In Regional leadership in the global system: Ideas, interests and strategies of regional powers, ed. D. Flemes, 31-50. Farnham: Ashgate.

Linklater, A. 2005. Dialogic politics and the civilising process. Review of International Studies 31 (1): $141-154$.

De Lombaerde, P., F. Söderbaum, L. Van Langenhove, and F. Baert. 2010. The problem of comparison in comparative regionalism. Review of International Studies 36: 731-753.

Lopez Lucia, E. 2015. Regional powers and regional security governance: An interpretive perspective on the policies of Nigeria and Brazil. International Relations 29 (3): 348-362.

Lopez Lucia, E. 2018. Rethinking regionalism and the politics of regionalisation: The performance of ECOWAS's agency by Nigeria and the European Union. Journal of International Relations and Development 21 (3): 663-688.

Macron, E. 2018. Lettre au président de république de guinée equatoriale. Paris: Présidence de la République française.

Malamud, A. 2011. A leader without followers? The growing divergence between the regional and global performance of Brazilian foreign policy. Latin American Politics and Society 53 (3): 1-24.

Malamud, A. 2013. Overlapping regionalism, no integration: Conceptual issues and the Latin American experiences. EUI-RSCAS Working Paper 20, Florence: European University Institute.

Marten, K. 2019. Russia's use of semi-state security forces: The case of the Wagner Group. Post-Soviet Affairs 35 (3): 181-204.

Mattheis, F. 2017. Towards bifurcated regionalism - the production of regional overlaps in Central Africa. In The new politics of regionalism - perspectives from Africa, Latin America and Asia-Pacific, ed. A. Dietze, et al., 37-51. London: Routledge.

Mattheis, F. 2017. Repositioning Europe in the study of regions: comparative regionalism interregionalism and decentred regionalism. Journal of European Integration 39 (4): 477-482.

Mattheis, F. 2021. Regionalism and interregionalism in EU-Africa relations. In The Routledge Handbook on EU-Africa Relations, ed. T. Haastrup, L. Mah and N. Duggan, 26-37. Abingdon: Routledge.

Mattheis, F., and U. Wunderlich. 2017. Regional actorness and interregional relations: ASEAN, the EU and Mercosur. Journal of European Integration 39 (6): 723-738.

Mattli, W. 1999. The logic of regional integration: Europe and beyond. Cambridge: Cambridge University Press.

Mbadinga, M.I. 2001. The Inter-African mission to monitor the implementation of the Bangui agreements (MISAB). International Peacekeeping 8 (4): 21-37.

Metelits, C. 2016. Challenging US security assessments of Africa. African Security 9 (2): 89-109.

Meyer, A. 2011. Economic community of central african states. In The democratization of international organizations: First international democracy report 2011, ed. G. Finizio, L. Levi, and N. Vallinoto. International Democracy Watch: Moncalieri.

Milani, C.R., L. Pinheiro, and M.R.S. De Lima. 2017. Brazil's foreign policy and the 'graduation dilemma.' International Affairs 93 (3): 585-605.

Mitchell, D. 2016. Regional power? Yes, but what kind. Paper presented at the International Studies Association Convention Asia-Pacific.

Médard, J.F. 2005. France and sub-Saharan Africa. In Africa and the north: Between globalization and marginalization, ed. U. Engel and G. Rye Olsen, 38-54. London: Routledge.

Nolte, D. 2010. How to compare regional powers: Analytical concepts and research topics. Review of International Studies 36 (4): 881-901.

Nubukpo, K. 2007. Politique monétaire et servitude volontaire. Politique Africaine 1: 70-84.

Nubukpo, K., M. Ze Belinga, B. Tinel, and D.M. Dembélé, eds. 2016. Sortir l'Afrique de la servitude monétaire. À qui profite le franc CFA? Paris: La Dispute.

Nye, J.S. 2004. Power in a global information age. New York: Routledge.

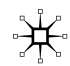


OECD. 2020. Development co-operation profile France. Paris: OECD. https://www.oecd-ilibrary.org/ sites/29927d90-en/index.html?itemId=/content/component/5e331623-en\&_csp_=b14d4f6050 5d057b456dd1730d8fcea3\&itemIGO=oecd\&itemContentType=chapter. Accessed 29 July 2021.

De Oliveira, R.S. 2007. Oil and politics in the gulf of guinea. New York: Columbia University Press.

Pace, M., P. Seeberg, and F. Cavatorta. 2009. The EU's democratization agenda in the Mediterranean: A critical inside-out approach. Democratization 16 (1): 3-19.

Dal Parlar, E. 2016. Conceptualising and testing the 'emerging regional power'of Turkey in the shifting international order. Third World Quarterly 37 (8): 1425-1453.

Paul, T.V., D.W. Larson, and W.C. Wohlforth, eds. 2014. Status in world politics. Cambridge: Cambridge University Press.

Peiffer, C., and P. Englebert. 2012. Extraversion, vulnerability to donors, and political liberalization in Africa. African Affairs 111 (444): 355-378.

Perdriel-Vaissière, M. 2017. France's biens mal acquis affair: Lessons from a decade of legal struggle. New York: Open Society Foundation. https://www.opensocietyfoundations.org/sites/default/ files/legal-remedies-11-perdriel-20170612.pdf. Accessed 29 July 2021.

Presidency of the Republic of Cameroon. 2020. Déplacements et visites. https://www.prc.cm/fr/actua lites/deplacements-et-visites. Accessed 29 July 2021.

Profant, T. 2010. French geopolitics in Africa: From neocolonialism to identity. Perspectives: Review of Central European Affairs 18 (1): 41-61.

Prys, M. 2010. Hegemony, domination, detachment: Differences in regional powerhood. International Studies Review 12 (4): 479-504.

Reich, S., and R.N. Lebow. 2014. Good-bye hegemony!: Power and influence in the global system. Princeton: Princeton University Press.

Riggirozzi, P., and D. Tussie. 2012. The rise of post-hegemonic regionalism in Latin America. In The rise of post-hegemonic regionalism, ed. P. Riggirozzi and D. Tussie, 1-16. Dordrecht: Springer.

Rye Olsen, G. 2017. The ambiguity of US foreign policy towards Africa. Third World Quarterly 38 (9): 2097-2112.

Schirm, S.A. 2010. Leaders in need of followers: Emerging powers in global governance. European Journal of International Relations 16 (2): 197-221.

Schoeman, M. 2015. South Africa as an emerging power: From label to 'status consistency'? South African Journal of International Affairs 22 (4): 429-445.

Senate, French. 2013. Rapport d'information fait au nom de la commission des affaires étrangères, de la défense et des forces armées par le groupe de travail sur la présence de la France dans une Afrique convoitée. Paris: Sénat.

Shaw, T.M., J.A. Grant, and S. Cornelissen, eds. 2011. The Ashgate research companion to regionalisms. Farnham: Ashgate.

Soares de Lima, M.R., and M. Hirst. 2006. Brazil as an intermediate state and regional power: Action, choice and responsibilities. International Affairs 82 (1): 21-40.

Söderbaum, F. 2015. Rethinking regionalism. London: Palgrave Macmillan.

Söderbaum, F., and P. Stålgren, eds. 2010. The European Union and the Global South. Boulder: Lynne Rienner Publishers.

Söderbaum, F. 2013. What's wrong with regional integration? The problem of eurocentrism. EUI-RSCAS Working Paper No. 64. Florence: European University Institute.

Taylor, I. 2011. South African 'imperialism'in a region lacking regionalism: A critique. Third World Quarterly 32 (7): 1233-1253.

Taylor, I. 2019. France à fric: The CFA zone in Africa and neocolonialism. Third World Quarterly 40 (6): 1064-1088.

The Economist. 2019. Air strikes in the desert: France is propping up a strongman in Chad. 16 February. https://www.economist.com/middle-east-and-africa/2019/02/16/france-is-propping-up-a-stron gman-in-chad. Accessed 29 July 2021.

Tolstrup, J. 2015. Black knights and elections in authoritarian regimes: Why and how Russia supports authoritarian incumbents in post-S oviet states. European Journal of Political Research 54 (4): 673-690.

Towfigh Nia, O. 2020. Russia building military bases in Africa: Report. Andalou Agency. https://www. aa.com.tr/en/africa/russia-building-military-bases-in-africa-report-/1931550. Accessed 6 Aug 2021.

UN Security Council. 2013. Security Council resolution 2127 on the situation in the Central African Republic. New York: UN Security Council. 
UN COMTRADE. 2020. UN COMTRADE database. https://comtrade.un.org/. Accessed 29 July 2021.

UNECA. 2020. Africa regional integration index report 2019. Addis Ababa: UNECA.

UNICEF. 2021. Migration profiles. https://esa.un.org/miggmgprofiles/. Accessed 29 July 2021.

Vallin, V.M. 2015. France as the gendarme of Africa, 1960-2014. Political Science Quarterly 130 (1): $79-102$.

Vignal, F. 2019. Tchad: Pourquoi la France est intervenue avec ses Mirage 2000 pour défendre Idriss Déby. Public Sénat.

Volgy, T.J., P. Bezerra, J. Cramer, and J.P. Rhamey Jr. 2017. The case for comparative regional analysis in international politics. International Studies Review 19 (3): 452-480.

Welz, M. 2016. Multi-actor peace operations and inter-organizational relations: Insights from the Central African Republic. International Peacekeeping 23 (4): 568-591.

Wigell, M. 2016. Conceptualizing regional powers' geoeconomic strategies: Neo-imperialism, neo-mercantilism, hegemony, and liberal institutionalism. Asia Europe Journal 14 (2): 135-151.

Womack, B. 2016. Asymmetry and international relationships. Cambridge: Cambridge University Press.

World Bank. 2021. GDP data per Country. https://data.worldbank.org/indicator/NY.GDP.MKTP.CD. Accessed 29 July 2021.

Østerud, Ø. 1992. Regional great powers. In Regional great powers in international politics, ed. I. Neumann, 1-15. London: Palgrave Macmillan.

Publisher's Note Springer Nature remains neutral with regard to jurisdictional claims in published maps and institutional affiliations. 